\title{
Feasibility study of floating solar panels over lakes in Bengaluru City, India
}

V. Yashas BEng

Undergraduate student, Department of Civil Engineering, Rashtreeya Vidyalaya College of Engineering, Bengaluru, India (Orcid:0000-00033662-714X) (corresponding author: yashasv.cv17@rvce.edu.in)
Bagrecha Aman BEng

Undergraduate student, Department of Civil Engineering, Rashtreeya Vidyalaya College of Engineering, Bengaluru, India (Orcid:0000-00032931-0777)

S. Dhanush MTech

Assistant Professor, Department of Civil Engineering, Rashtreeya Vidyalaya College of Engineering, Bengaluru, India (Orcid:0000-0003-3293-0205)

\begin{abstract}
Sustainable energy production has become an issue of prime concern for regions across the globe. With all the global bodies urging nations to explore and adopt clean sources of energy, India's enormous solar potential provides a sustainable source of energy, replacing conventional sources that are both polluting and rapidly depleting. To produce large amounts of solar energy, solar parks spanning across large areas are required, making it impossible to serve in highly populated cities like Bengaluru, where spacious lands are not available. The rooftop solutions contribute very minimally towards the city's energy demand because of the dense urban cover and congested planning. But the city has a large number of water bodies including tanks, large lakes and reservoirs. This paper studies the floating solar photovoltaic (FSPV) technology to provide an alternative solar route to harness sustainable energy. In this study, 32 lakes within the city limits were considered spanning across 3294 ac of lake area and analysed for the climatic suitability of FSPV systems, solar output assessment and estimation of evaporation losses. The study found that the FSPV systems adopted on lakes with a coverage ratio of $0.5-0.6$ could meet an average of $26 \%$ of the city's annual power demand.
\end{abstract}

Keywords: infrastructure planning/renewable energy/town and city planning

\section{Notation}

$A, B, C$ parameters of Antoine equations

$E_{\mathrm{L}} \quad$ lake evaporation ( $\mathrm{mm} /$ day)

$\underline{\mathrm{e}}_{\mathrm{a}} \quad$ actual vapour pressure of overlying air at a specified height $(\mathrm{mmHg})$

$e_{\mathrm{w}} \quad$ saturated vapour pressure at the water surface temperature $(\mathrm{mmHg})$

$K_{\mathrm{M}} \quad$ Mayer's coefficient accounting for various other factors with a value of 0.36

$P \quad$ saturated vapour pressure $(\mathrm{mmHg})$

$T \quad$ mean temperature (celsius)

$u_{9} \quad$ monthly mean wind velocity in about $9 \mathrm{~m}$ above ground $(\mathrm{km} / \mathrm{h})$

\section{Introduction}

India is exposed to an enormous potential of solar energy; it is estimated to be around 5000 trillion $\mathrm{kWh}$ over India's land area. Currently, solar energy is being harvested by way of solar thermal plants, terrestrial solar parks and roof-mounted photovoltaic (PV) systems. Globally, since the first floating solar photovoltaic (FSPV) system was installed in 2007 in Japan, the market has undergone exponential growth and is currently projected to reach at least $3 \mathrm{GW}$ capacity by 2024 (Acharya and Devraj, 2019). With the Indian government aiming to achieve $175 \mathrm{GW}$ of renewable energy by 2022, of which $100 \mathrm{GW}$ from solar is planned under the National Solar Mission (IEA, 2021), such long-term development goals and the PV module prices reaching affordable rates make it a viable option to harness the solar energy potential to meet the energy demands. Bengaluru is projected to be the fastest-growing regional economy in the world, with the city's gross domestic product growth forecasted to reach $8.5 \%$ year by year, by 2035 (Oxford Economics, 2020). This high-paced development would increase the city's energy demand and also lead to larger competing uses for land. Rooftop solar initiatives have failed to gain traction in the city due to residential complexes, which form the majority of urban spaces, having a very small ratio of roof space to available floor space (Ishwara et al., 2017). The rooftop installations require continuous public participation, as funding the solar set-up and maintenance must be managed largely by the consumers or property owners. Added to this is the prolonged time needed for a return on the invested capital. In some regions with high population densities, the PV applications in rooftops face stiff competition from rooftop gardening (Liu et al., 2017). Due to these reasons, consumers are not encouraged to adopt rooftop solar solutions. With the lack of available of large parcels of land to establish terrestrial solar parks and some implementation problems faced in rooftop solar installations, FSPV technologies widen the scope of solar power integration into grids. This study aims to investigate the scope of FSPV systems in providing sustainable energy by focusing on understanding the compatibility of FSPV systems in the regions that have high population densities and competing uses for available land in the case of Bengaluru City. The study checks for the climatic suitability and energy capacity of FSPV systems over water bodies involving tanks, lakes and reservoirs in the Bengaluru region. The methodology primarily focuses on the estimation of solar energy output, evaporation losses and cost estimation for the lakes 
considered in the study. The workflow adopted includes the study of the climatic variables of temperature, wind velocity, solar radiation and its suitability with the Ciel \& Terre floating system. This study does not account for the field studies on the considered water bodies and the impact of the FSPV cover on the lakes' ecosystem.

\section{Literature review}

This section aims to present a brief review of the parameters that control the FSPV technology during the design, implementation and maintenance stages of projects.

\subsection{Performance of floating solar photovoltaic systems}

This section discusses the performance of FSPV systems used across various types of water bodies. This section also compares the behaviour of FSPV systems relative to ground-based PVs. Comparing ground-mounted PV with FSPV in the state of Hapcheon, China, the performance of 100 and $500 \mathrm{~kW} \mathrm{FSPV}$ was compared with that of $1 \mathrm{MW}$ PV plant $60 \mathrm{~km}$ south of Hapcheon, having similar global horizontal irradiance (GHI) and mean temperature. It is observed that $100 \mathrm{~kW}$ FPV has an efficiency of $17.6 \%$ as compared to $13.5 \%$ of overland PV (Chio, 2014). The efficiency of any solar panel depends on its module temperature. The water-cooling effect ensures ambient working temperature for the FSPV module. It is observed that there is a $3.5^{\circ} \mathrm{C}$ difference between land-based PVs and FSPVs (Liu et al., 2017). It is also confirmed that FSPV systems produce at least $10 \%$ more energy than other land-based systems studied (Kamuyu et al., 2018). The reliability of 100 and $500 \mathrm{KW}$ shows that nominal power declines at the rate of $13.9 \%$ after 25 years. The lifetime of the PV module is currently in the range of 25 years and may reach 30 years in the near future. Power module warranty typically guarantees that after the first 10-12 years, the output power of the module will be at least $90 \%$ of its initial nominal power and that after 20-25 years of operation, the output power of the module will be at least $80 \%$ of its initial nominal power (Green et al., 2012). A full-scale floating plant is located near Alicante, Spain, which was built in an agriculture reservoir to study the behaviour of the system. The top of the reservoir has a surface area of $4700 \mathrm{~m}^{2}$, but only $7 \%$ of such area has been covered with a fixed solar system. The cost of setting up FSPV systems was nearly $30 \%$ higher than a conventional grid (FerrerGisbert et al., 2013). This is due to the need for additional components such as mooring systems and supporting platforms. Added to this is the material requirement of FSPV systems to resist harsher environments than land conditions. In a study conducted by Rosa-Clot et al., the authors estimated the cost of setting up $1 \mathrm{MW}$ (1048 KW) fixed floating PV to be US\$1 081398 (Rosa-Clot et al., 2017). With the enhanced performance of FSPV relative to terrestrial $\mathrm{PV}$, the focus moved towards optimising the systems supporting the $\mathrm{PV}$ modules in a water environment.

\subsection{Review of floating solar photovoltaic technologies}

The first floating structure dates back to 2007 (Trapani and Redón Santafé, 2015). In the initial days, pontoons were used to mount the FSPV system. Although robust in its structure, it was expensive and not specifically designed for the FSPV (Rosa-Clot and Tina, 2018). Only recently, an alternative approach to utilise high-density polyethylene (HDPE) as a floating structure with galvanised steel supporting it became very popular due to its low manufacturing cost (Sahu et al., 2016). Few plants were set up with this technology, which proved to be successful (Cazzaniga et al., 2018) Other companies followed suit and proposed an innovative solution to use plastic as the base material (Trapani and Redón Santafé, 2015). One such company, Ciel \& Terre, utilised 100\% HDPE and build a modular, robust floating structure (Rosa-Clot and Tina, 2018). This became widely popular and currently has the most installed capacity (Oliveira-Pinto and Stokkermans, 2020). It meets the criteria of modularity, flexibility, robustness and safety, and thus, this floating structure has been adopted for the study. Both the enhanced performance of FSPV and the availability of scalable supporting structures meant that the focus moved towards accurately estimating the solar energy at a given site.

\subsection{Energy-estimation methods of floating solar photovoltaic generation}

With governments and institutions across the world incentivising the implementation of clean energy, these efforts have led to the availability of open-source energy estimation software. Widely used open-source software includes RETScreen (Natural Resources Canada), PVWatts (National Renewable Energy Laboratory, USA) and PVGIS (European Commission). PVWatts was incorporated in the study, due to the availability of NREL's international data set, its features to create intuitive shapes on lake bodies in addition to having produced energy corrected to PV cell temperature, allowing for realistic forecasts (Psomopoulos et al., 2015).

\subsection{Impact of floating solar panels on evaporation}

Due to increasing concern over climate change, the conservation of water becomes extremely vital. An FSPV structure has its application in reducing water evaporation from water bodies. The rate of evaporation mainly depends on two factors: vapour pressure of air temperature and wind speed at a height of $10 \mathrm{~m}$.(Rosa-Clot et al., 2017). FSPV systems can help save up to $33 \%$ of the water from evaporating on a natural lake (Sahu et al., 2016). A feasibility study considering $1 \mathrm{MW}$ FSPV was carried out over the Kishore Sagar dam in Kota, Rajasthan, India. The authors estimated the plant to generate $18,38,519 \mathrm{kWh}$ of energy per year while saving 37 million litres of water from evaporation (Mittal et al., 2017). A similar study aimed at analysing large reservoir potential across the whole of India. It was found that for each square kilometre of area, 1250 million litres of water per year could be saved from evaporating (Sharma and Kothari, 2016). On analysing electrical generation and reduction in evaporation at a reservoir in Spain, it is seen that when the entire structure was covered with FSPV, it generated $425000 \mathrm{kWh}$ per year, saving $5000 \mathrm{~m}^{3}$ of water by covering a $4490 \mathrm{~m}^{2}$ surface reservoir with floating PVs, which is $25 \%$ of the total reservoir capacity (Redón Santafé et al., 2014).

\subsection{Environmental impacts of floating solar photovoltaic systems}

The benefits of setting FSPV plant outweigh the drawbacks, especially in an urban landscape where lakes offer a stable environment for FSPV 
systems to perform and maintain due to proximity with technical logistics. Although there has been concern regarding FSPV having an impact on the quality of water and flora-fauna due to increased turbidity on installing mooring and shallowers (Serrano et al., 2016) the scale of the impact is site specific. Moreover, since waterbodies under consideration are lakes within the city bounds, the footprint of the project would be small, thus causing minimum to no harm to flora-fauna while increasing water quality by reducing algal bloom and decreasing the evaporation rate (Oliveira-Pinto and Stokkermans, 2020; Pimentel Da Silva and Branio, 2018). Even under these site conditions, precautions have to be taken to ensure that the material to be used is recyclable and the water to be used for cleaning is nondetergent. Furthermore, regular check and maintenance would allow the proper and efficient functioning of the FSPV system.

The various aspects of FSPV integration covering performance, energy-estimation and environmental benefits have been extensively studied for large water bodies, like reservoirs and dams. There have been no similar studies conducted on smaller water bodies in urban areas. This study explores the suitability of using a large number of small waterbodies for solar energy generation in the urban set-up of Bengaluru City. The study solely covers energy estimation, quantifies the evaporation loses and provides a cost estimate. However, it does not include field studies and the environmental impact of solar panels on the lakes' ecosystem.

\section{Suitability of floating solar photovoltaic systems for Bengaluru City}

Bengaluru is located at an elevation of $920 \mathrm{~m}$ on two river basins, namely, Cauvery and Dakshina Pinakini. The natural flow of water is away from the city into the neighbouring valleys. This historically allowed the development of well-connected cascading water management systems spreading across the city, resulting in the excess of 200 water bodies involving irrigation ponds and large storage lakes. Since the 1990s, due to rapid urbanisation, the city has sprawled extensively and, in the process, several lakes have been converted into stadiums, administrative buildings, sewage-treatment units and so on. Although, with governments extensively focusing on rejuvenation projects, currently, the city has over 197 lakes in existence. The following points address the benefits of having FSPV systems:

- Addressing summer power demand, FSPVs would generate maximum power during the summer months, and be vital in supplying power to peak summer demand. The power generated would be amidst demand centres, reducing the burden on the state's thermal plants located far away. The life cycle greenhouse gas emissions due to PV are estimated to be $46 \mathrm{~g}$ carbon dioxide $\left(\mathrm{CO}_{2}\right)$ per kilowatt-hour compared to $164 \mathrm{~g}$ carbon dioxide per kilowatt-hour, which are emitted out of thermal plants, effectively reducing carbon footprint by $70 \%$ (NREL, 2012).

n The presence of FSPV modules causes shading over the water surface, reduced temperature and intercepted winds. This reduces the rate of evaporation and saves large quantities of water that can be used by the local population for both potable and non-potable uses, depending on the quality of the lake (Sahu et al., 2016).

- Excessive algal growth limits light penetration through the water, adversely impacting the growth of plants and survival of fishes, choking the entire ecosystem in the long run. The reduction of light controls algal growth. Hence, FSPV creates less favourable conditions for algal blooms, improving the quality of lakes. The limit to which algal blooms can be eliminated depends on the coverage area of solar panels (Haas et al., 2020).

- With the electric vehicle (EV) industry gaining traction in the state, the government is expecting to attract US\$4.24 billion of investment, and incentives are being given for establishing charging infrastructure (Commerce and Industries Department -

Government of Karnataka, 2017). Charging stations can be based on photovoltaic-electric vehicle (PV-EV) integration using FSPV systems that would be widespread across the city. This would help in the electrification of vehicles and also drastically reduce the payback period of floating solar projects as a whole (Singh et al., 2019).

- Most lakes in the city have restrictions to be used for swimming, fishing or any recreational activity. Such water bodies are not considered in the study. The water bodies in the city used for annual religious activities and navigation purpose are also not considered in the study.

FSPV has a wide range of benefits over land-based systems, such as the use of redundant areas, improved performance of PVs by 10-20\%, less prone to external shading, less soiling (coverings that could obstruct light like dust and leaves) losses and easier installation (Sahu et al., 2016). The above-mentioned benefits will increase the premium of lakes apart from recreation in an urban set-up, encouraging better protection and conservation of lakes through strict law enforcement.

\section{Data and methodology}

The workflow mainly focuses on two control parameters. Firstly, the climatic parameters of wind velocity, solar radiation and temperature are studied. The variation of climatic parameters in the study area is compared and checked for compatibility with the floating system. It then considers the lake bodies and forecasts the energy produced using PVWatts. Later, the evaporation losses are quantified using Mayer's model. Lastly, a preliminary cost estimate is provided using the total coverage area and the PV module specifications. The workflow incorporated in estimating energy, evaporation losses and the cost is shown in Figure 1.

\subsection{Floating solar photovoltaic system design \\ 4.1.1 Floating photovoltaic system}

The authors considered a versatile technology called Hydrelio ${ }^{\circledR}$ patented by Ciel \& Terre. The PVs are mounted on a floating structure, composed of several floats connected together. The floating platform is composed of primary floats for supporting the PVs and secondary floats for maintenance, buoyancy and spacing the PVs appropriately. These are interconnected using fiberglass pins. The floats can be used along with $60 / 72$ cells' PV modules. A hole in the middle, for 
Smart Infrastructure and Construction Volume 174 Issue 1
Feasibility study of floating solar panels

over lakes in Bengaluru City, India

Yashas, Bagrecha and Dhanush

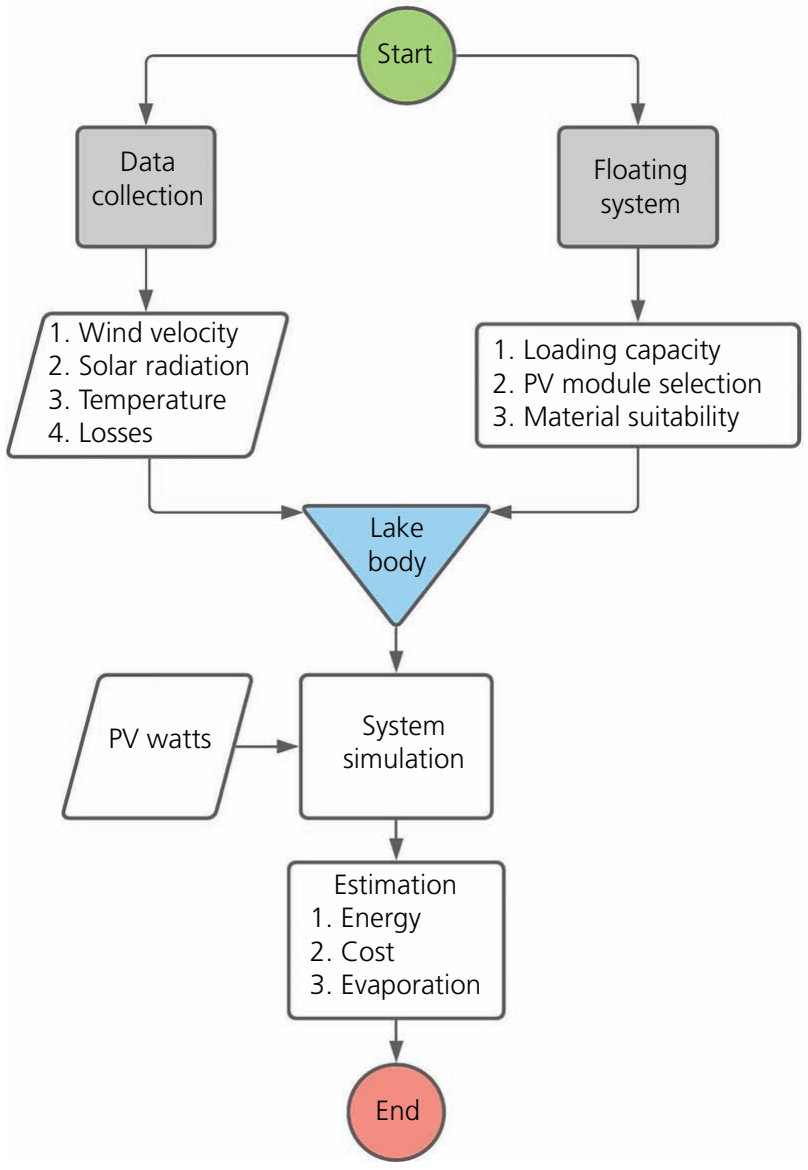

Figure 1. Overview of methodology. PV, photovoltaic

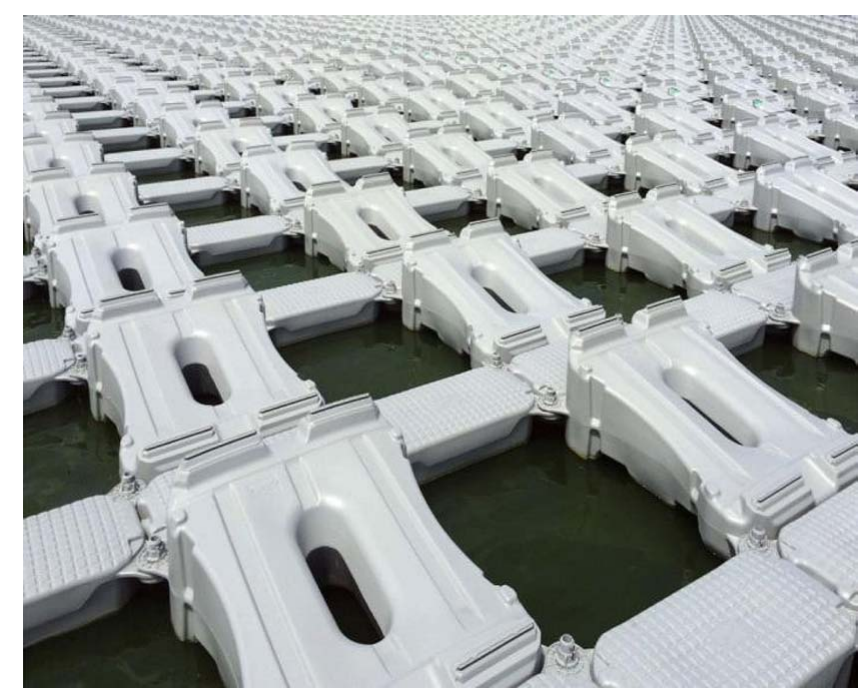

Figure 2. Hydrelio floating structure

passively cooling and ventilating the PV panel, is provided in the primary float, as shown in Figure 2. PV modules can be attached to the float using aluminium/fiberglass rails. The anchoring system involves two methods: one at the bottom of the lake in case of shallow depth bodies, and the other being on the shore when the depth is extensive. The construction involves no heavy machinery; the materials used are non-corrosive and are UV resistant, and they can withstand high wind velocities up to $58.3 \mathrm{~m} / \mathrm{s}$ (Dizier et al., 2018) and can also be used in lakes that are used for drinking water purposes, as it is tested to be BS: 6920:2000 compliant (BSI, 2000). The maximum tolerable water flow is $1 \mathrm{~m} / \mathrm{s}$, considering waves and their dynamic effects. The tested cooling processes involve immersion cooling, forced water circulation and spraying. According to the specifications of Hydrelio, ASM-7PERC-AAA modules are chosen as the test PV modules, and their specifications were used in all calculations.

\subsubsection{Floating solar losses}

The Central Electricity Regulatory Commission's report (Sharma, 2011) on the performance of solar plants in India has extensively studied the behaviour of existing terrestrial and floating solar plants in the country. The report's recommended values were considered for soiling, shading, wiring, nameplate rating, for snow, mismatch, connections, light-induced degradation, age and availability, as shown in Table 1 .

\subsection{Bengaluru's energy demand}

BESCOM (Bangalore Electricity Supply Company Limited) is responsible for delivering power to the city and seven other districts, namely, Bangalore Rural, Chikkaballapura, Kolar, Davanagere, Tumkur, Chitradurga and Ramanagara. It has a demand roughly close to half of the total energy demand of the state, out of which the city accounts for $50 \%$. In total, Bengaluru alone constitutes $25 \%$ of the state's energy demand (BESCOM, 2018). The mean monthly demand of Bengaluru City supplied by BESCOM for the year 2018-2019 is shown in Figure 3. The power demand of the city witnesses' peaks in February, March and April. This can be attributed to the increased usage of fans, air conditioners and also pumps. The power demand reduces in the monsoon season due to reduced cooling needs for domestic and commercial purposes.

\subsection{Suitability of climatic parameters}

Climate parameters are important in assessing the suitability of an area for FSPV projects. Temperature controls the efficiency of energy conversion. Wind velocity is a design parameter that determines the specification of supporting platforms. Finally, solar radiation determines the amount of energy received at the location.

\section{Table 1. System losses considered for analysis}

$\begin{array}{lc}\text { Losses } & \text { Value: \% } \\ \text { Soiling } & 1 \\ \text { Shading } & 3 \\ \text { Mismatch } & 1 \\ \text { Wiring } & 1 \\ \text { Light-induced degradation } & 1.5 \\ \text { Miscellaneous } & 2.5\end{array}$


Feasibility study of floating solar panels

over lakes in Bengaluru City, India

Yashas, Bagrecha and Dhanush

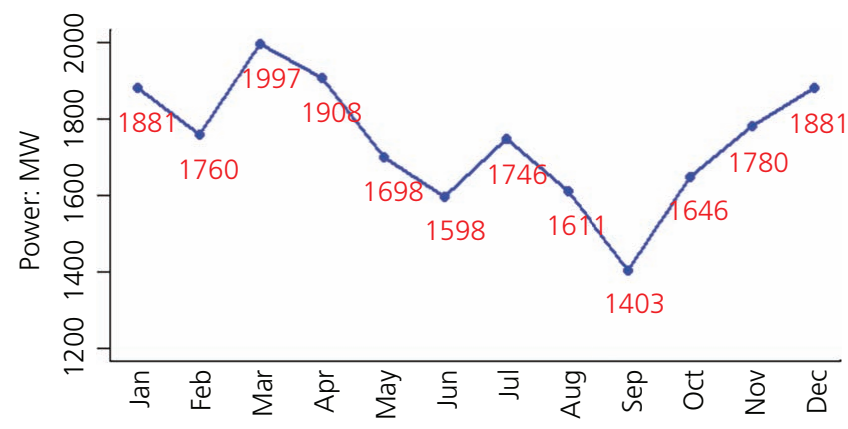

Figure 3. Mean monthly demand to be supplied by BESCOM

\subsubsection{Temperature}

The city records an average annual temperature of $23.5^{\circ} \mathrm{C}$, and the variation of monthly mean temperature is depicted in Figure 4. Generally, module performance is rated at $25^{\circ} \mathrm{C}$, beyond which the module output decreases. The city would provide an ambient temperature range and contribute to reduced losses due to temperature variation. Ideally, solar plants having at least $4 \mathrm{~h}$ of sunshine are best suited for PV working. Bengaluru receives a yearly average of $8.5 \mathrm{~h}$ of sunshine (Tyagi, 2009), making it a suitable location for adopting FSPV systems.

\subsubsection{Wind velocity}

According to the India Meteorological Department (IMD) data, the average annual wind velocity is $2.67 \mathrm{~m} / \mathrm{s}$ (Tyagi, 2009). The monthly wind velocity data is shown in Figure 6 . The wind complements the cooling effect of water and ensures the higher working efficiency of the system. Higher winds are naturally experienced during the monsoon season. The city experiences much lower velocities compared to the maximum allowable wind speed for the Hydrelio system of $58.3 \mathrm{~m} / \mathrm{s}$, and hence, there would be a less need for structural reinforcement to withstand wind loads.

\subsubsection{Floating solar photovoltaic system solar radiation}

The city receives an annual average solar radiation ranging between 5.5 and $6\left(\mathrm{kWh} / \mathrm{m}^{2}\right) /$ day. The monthly variation of daily mean

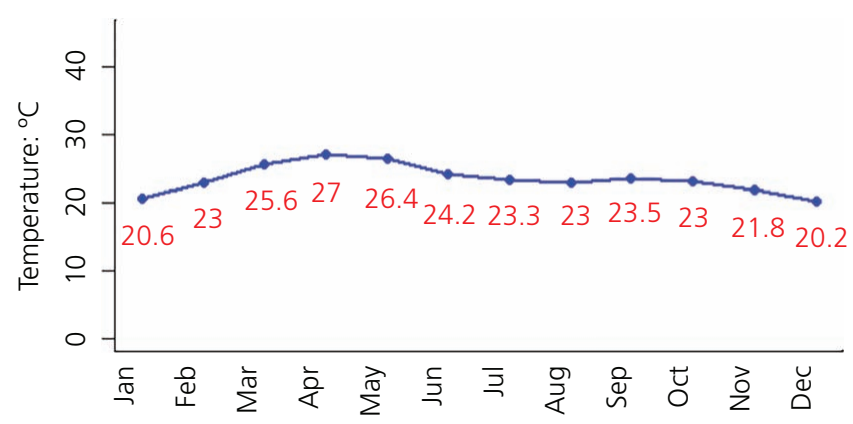

Figure 4. Mean monthly air temperature sunshine hours is shown in Figure 5. In this study, GHI was firstly obtained from the IMD database, which is based on ground measurement at the city's measuring station, and secondly, the NREL database, which is based on satellite measurements, that is often regarded to slightly overestimate values. The optimum database considering both is shown in Figure 7.

\subsection{Water bodies considered}

The lakes considered were primarily based on size criteria having an area greater than $20 \mathrm{ac}$. Also considering the scope of establishing electric charging stations within Bengaluru City, lakes having lesser areas closer to commercial areas were also considered. In total, 32 lakes (Table 2) spread across the city, covering industrial areas; residential colonies and also lakes adjacent to the airport were considered. The average power generated per day in megawatts (MW) was derived from the expected total annual output of the alternating current (AC) energy (kilowatt-hour per year) of the system. The spatial spread of the lakes is shown in Figure 8.

\subsection{Performance of floating solar photovoltaic system 4.5.1 Energy yield assessment}

PVWatts, an estimation tool developed by the national laboratory of the US Department of Energy was used in assessing the energy output. It estimated the annual energy yield based on the monthly

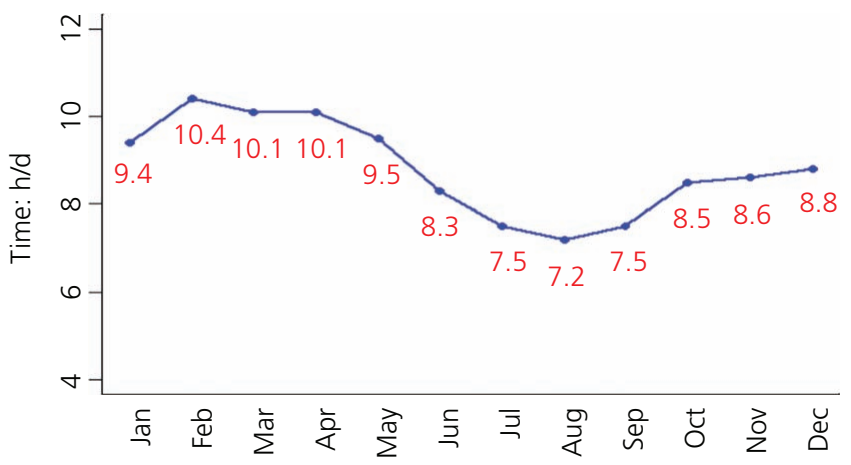

Figure 5. Mean monthly variation of daily sunshine hours

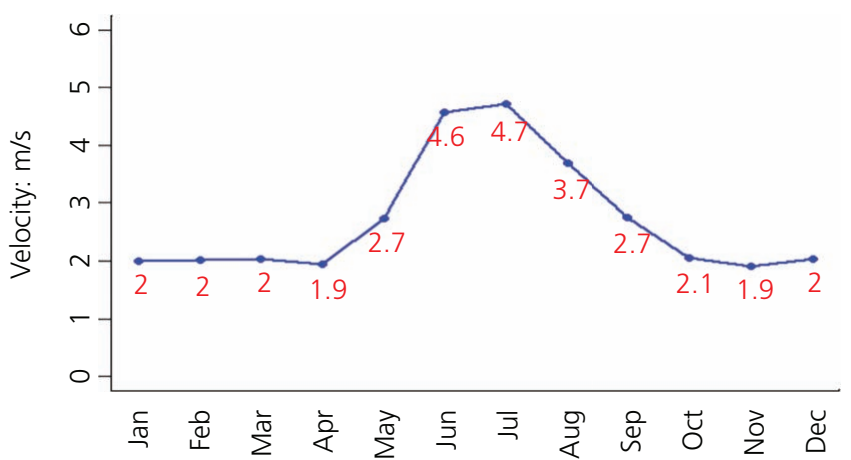

Figure 6. Mean monthly wind velocity 
average values of global solar radiation on a horizontal surface. The open-source software was synchronised with the Indian database, and validation studies showed an annual deviation ranging between -4 and $-6 \%$ (Psomopoulos et al., 2015). The study considered fixed solar modules having a nominal efficiency of $15 \%$ and an area coverage ratio of $0.5-0.6$. Figure 9 shows the expected mean monthly solar output. Naturally, high output is witnessed during the summer months and reduced output during the monsoon season. The

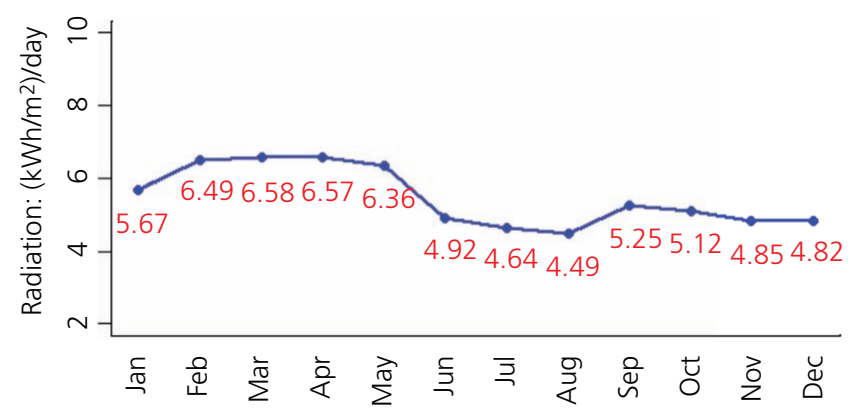

Figure 7. Mean monthly solar radiation analysis showed an average of $459 \mathrm{MW}$ of power from $3954 \mathrm{ac}$ of the lake area. Among the 32 lakes considered, 7 lakes produced more than $25 \mathrm{MW}$ and 9 lakes had a capacity lesser than $5 \mathrm{MW}$. On average, $8.5 \mathrm{ac}$ of land was needed to generate $1 \mathrm{MW}$ of power. Notably, Bettakote Lake, located adjacent to the city's airport, has a capacity of $13 \mathrm{MW}$, which can compensate at an average of $65 \%$ of the demand and contribute to the existing rooftop solar capacity of 8.35 MW, enabling complete sustainable functioning of the airport (Philip, 2018), Compared to the total demand of the city, the lakes can collectively generate an average of $26 \%$ of the power to be supplied. The monthly variation of the percentage of solar power of the demand is depicted in Figure 10. These values were obtained from total monthly output of AC energy ( $\mathrm{kWh} /$ month) across all water bodies considered.

\subsubsection{Estimation of evaporation losses}

Water preservation and evaporation reduction occur due to the installation of floating solar systems on lakes, dams, irrigation ponds and reservoirs. The area covered by FSPV will result in the reduction of evaporation over the lakes. Evaporation loss has been studied over lakes using Mayer's empirical formula given by Equation 1 (Subramanya, 2013):

Table 2. List of lakes considered for the study

\begin{tabular}{|c|c|c|c|}
\hline SI. number & Lake name & MW & Land area: ac \\
\hline 1 & Manchanbele Reservoir & 27 & 232 \\
\hline 2 & Thippagondanahalli Reservoir & 55 & 468 \\
\hline 3 & Kaggadasapura Lake & 8 & 51 \\
\hline 4 & Huvineane & 12 & 107 \\
\hline 5 & Konnasandra & 3 & 23 \\
\hline 6 & Gunjur & 6 & 48 \\
\hline 7 & Begur & 6 & 53 \\
\hline 8 & Hulimavu & 4 & 32 \\
\hline 9 & Bhimana Kuppe Kere & 4 & 37 \\
\hline 10 & Kengeri Lake & 2 & 18 \\
\hline 11 & Vrishabhavathi Reservoir & 52 & 462 \\
\hline 12 & Sulikere & 7 & 55 \\
\hline 13 & Hennagara Lake & 22 & 189 \\
\hline 14 & Muthanallur Lake & 18 & 153 \\
\hline 15 & Bellandur Lake & 37 & 219 \\
\hline 16 & Varthur Lake & 20 & 168 \\
\hline 17 & BTM Lake & 17 & 147 \\
\hline 18 & Yele Mallappa Shetty Lake & 30 & 261 \\
\hline 19 & Hesaraghatta tank & 50 & 426 \\
\hline 20 & Kasavanalli & 3 & 22 \\
\hline 21 & Venkatala & 14 & 137 \\
\hline 22 & Jakkur Lake & 8 & 60 \\
\hline 23 & Allalasandra & 2 & 16 \\
\hline 24 & Yelahanka Lake & 12 & 125 \\
\hline 25 & Kundalahalli Lake & 2 & 8 \\
\hline 26 & Hebbal Lake & 4 & 34 \\
\hline 27 & Suvarnamukhi Reservoir & 6 & 48 \\
\hline 28 & Rachenahalli Lake & 6 & 55 \\
\hline 29 & Agara Lake & 4 & 34 \\
\hline 30 & Bettakotte Lake (adjacent airport) & 13 & 116 \\
\hline 31 & Rayasandra Lake & 5 & 42 \\
\hline \multirow[t]{2}{*}{32} & Annekal Lake & 9 & 78 \\
\hline & Total & 459 & 3924 \\
\hline
\end{tabular}




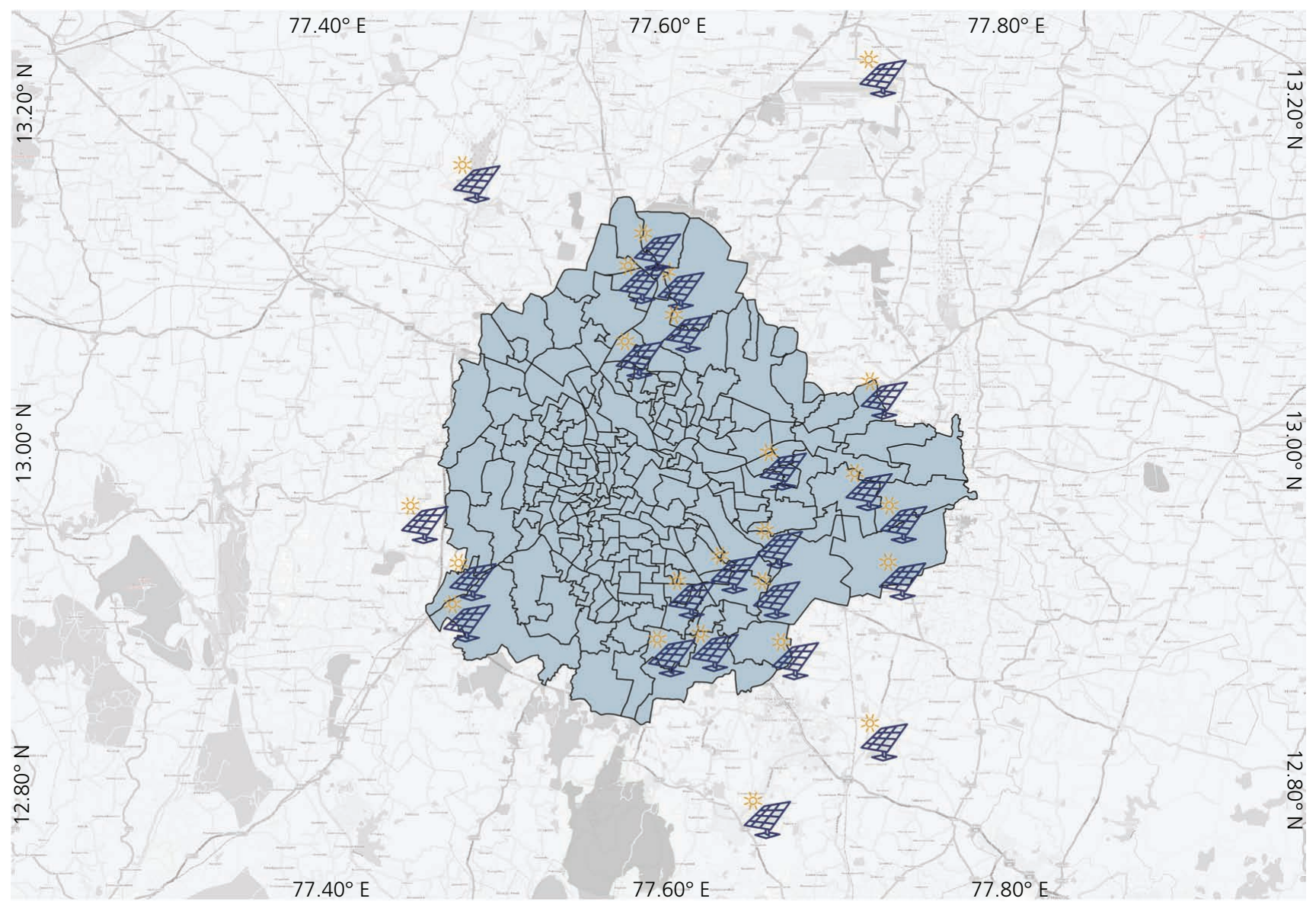

Figure 8. Spatial distribution of lakes

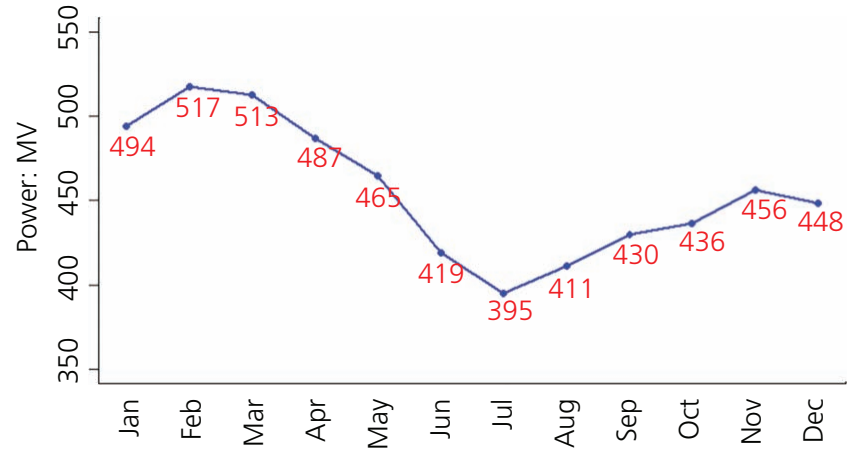

Figure 9. Mean monthly variation of output

1. $E_{1}=K_{\mathrm{M}}\left(e_{\mathrm{w}}-e_{\mathrm{a}}\right)\left(1+\frac{u_{9}}{16}\right)$

where $E_{1}$ is the lake evaporation $\left(\mathrm{mm} /\right.$ day), $e_{\mathrm{w}}$ is the saturated vapour pressure at the water surface temperature $(\mathrm{mmHg}), e_{\mathrm{a}}$ is the actual vapour pressure of overlying air at a specified height

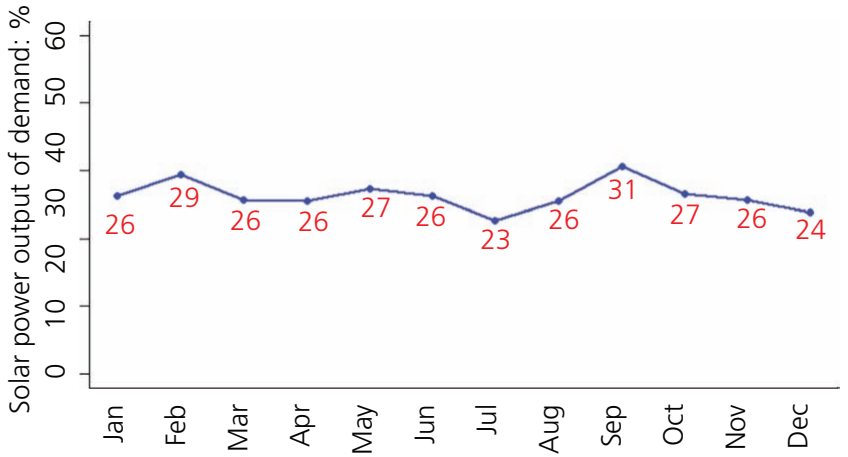

Figure 10. Monthly variation of output/demand

$(\mathrm{mmHg}), u_{9}$ is the monthly mean wind velocity in about $9 \mathrm{~m}$ above ground $(\mathrm{km} / \mathrm{h})$ and $K_{\mathrm{M}}$ is the coefficient accounting for various other factors with a value of 0.36 .

The actual vapour pressure and mean monthly temperature were obtained from the IMD data for evaluating the depth of lake evaporation per day. 
The saturated vapor pressure was calculated using the Antoine equation given by Equation 2 (Thomson, 1946):

$$
\text { 2. } R=10^{A}-\frac{R}{C+T}
$$

where $P$ is the saturated vapour pressure (mm of mercury $(\mathrm{Hg})$ ); $T$ is the mean temperature $\left({ }^{\circ} \mathrm{C}\right)$; and $\mathrm{A}, \mathrm{B}$ and $\mathrm{C}$ are Antoine equation parameters (Table 3 ).

Using the above formula, a reduction in evaporation loss is calculated and the final result has been summarised. Since the tilt angle of the panel is nearly zero, the result approximately spreads over the entire surface area. Annually, $22866653 \mathrm{~m}^{3}$ of water would be saved due to a reduction in evaporation calculated over 32 lakes. The monthly variation on evaporation losses is depicted in Table 4 .

\subsection{Cost estimation}

The cost of solar panels has seen an exponential decrease over the last decade. It is predicted that solar panels will decline in price by $4.4 \%$ each year through 2022. Most utility-scale solar farms will be installed for prices as low as US\$0.50 per watt in India (World Bank Group; Energy Sector Management Assistance Program; Solar Energy Research Institute of Singapore, 2019). Many manufacturers have a selling price of solar panels in the range of US\$0.4-0.44 per watt for $335 \mathrm{~W}$ monocrystalline solar panels. To generate $459 \mathrm{MW}$ of solar energy from FSPV, a total of 3788890 panels would be needed to be set up. This amounts to US\$500-560 million of investment in solar panels alone, as summarised in Table 5. Due to the variability of cost in inverters, floaters, anchoring and transportation, the price of setting up a plant can go up to US\$0.82 per watt. Evidently enough, as the system size increases, the levelled cost of electricity does not differ significantly from that of ground-mounted systems (Westoff and Lacey, 2017).

\section{Conclusion}

Solar energy is the most readily available source of clean energy over most parts of India. Using FSPV systems, this energy can be harnessed on areas that have no competitive use and is often closer to areas of consumption compared to conventional power plants. Bengaluru City's widespread lake network and ambient climatic conditions for PV modules can contribute towards harnessing clean energy and lead the city towards a sustainable future. A conservative assessment of the feasibility of such systems carried out in the present study is summarised in the following points:

- The 3924 ac of land considered over 32 lakes within the city at a coverage ratio of $0.5-0.6$, amounted to an annual average output of $459 \mathrm{MW}$ of power. An average of $8.5 \mathrm{ac}$ is needed per megawatt, compared to $7 \mathrm{ac} / \mathrm{MW}$ at the state's biggest terrestrial solar park in Pavagada, Tumkur, Karnataka, India.

- The FSPV systems adopted in the city would meet an average of $26 \%$ of the city's power demand, and due to the spatial spread of the lakes being within the vicinity of the city, this would significantly reduce the transmission losses and costs.

- The floating solar plants would also save water due to evaporation, resulting in annual savings of approximately 22866 million litres.

By moving towards FSPV integration into the city, the community could benefit in the following ways:

- FSPV systems encourage a faster and more economic development of solar projects, as it reduces the burden of land
Table 3. Antoine equation parameters

\begin{tabular}{|ccc|} 
A & B & C \\
\hline 8.07131 & 1730.63 & 233.426 \\
\hline
\end{tabular}

Table 5. Summary of cost analysis

$\begin{array}{lcc}\text { Annual energy } & \text { Number of } & \text { Cost of solar panels: cr. ₹ } \\ \text { generation: KWh } & \text { panels } & (1 \text { ₹ }=\text { US\$0.013) } \\ 4088504383 & 3788890 & 3681-4062\end{array}$

Table 4. Monthly variation of evaporation losses

\begin{tabular}{|c|c|c|c|c|c|c|c|}
\hline Month & $\begin{array}{c}\text { Mean } \\
\text { temperature: } \\
{ }^{\circ} \mathrm{C}\end{array}$ & $\begin{array}{c}\text { Vapour } \\
\text { pressure: } \\
\text { hPa }\end{array}$ & $\begin{array}{c}\text { Vapour } \\
\text { pressure: mm } \\
\text { Hg }\end{array}$ & $\begin{array}{l}\text { Saturated vapour pressure at } \\
\text { given temperature: } \mathrm{mm} \mathrm{Hg}\end{array}$ & $\begin{array}{l}\text { Wind } \\
\text { speed: } \\
\text { km/h }\end{array}$ & $\begin{array}{l}\text { Evaporation: } \\
\text { mm/day }\end{array}$ & $\begin{array}{l}\text { Loss every } \\
\text { month: } \mathrm{m}^{3}\end{array}$ \\
\hline January & 20.59 & 22.14 & 12.73 & 19.93 & 7.20 & 3.76 & 1737313.20 \\
\hline February & 22.96 & 24.08 & 13.01 & 22.41 & 7.25 & 4.92 & 2271770.05 \\
\hline March & 25.65 & 26.43 & 13.95 & 25.78 & 7.33 & 6.21 & 2867251.57 \\
\hline April & 27.01 & 27.87 & 16.26 & 28.05 & 6.99 & 6.10 & 2818031.43 \\
\hline May & 26.40 & 27.14 & 17.38 & 26.88 & 9.84 & 5.52 & 2551036.46 \\
\hline June & 24.20 & 24.93 & 17.64 & 23.58 & 16.47 & 4.34 & 2005025.21 \\
\hline July & 23.35 & 24.00 & 17.55 & 22.31 & 16.99 & 3.53 & 1630152.76 \\
\hline August & 22.99 & 24.14 & 17.53 & 22.49 & 13.27 & 3.27 & 1508773.04 \\
\hline September & 23.48 & 24.37 & 17.42 & 22.81 & 9.89 & 3.14 & 1448482.33 \\
\hline October & 23.03 & 24.11 & 17.03 & 22.46 & 7.40 & 2.86 & 1320686.12 \\
\hline November & 21.77 & 22.91 & 15.40 & 20.89 & 6.90 & 2.83 & 1305999.63 \\
\hline December & 20.22 & 21.80 & $\begin{array}{l}13.74 \\
\text { Annual t }\end{array}$ & tal water loss & 7.34 & 3.04 & $\begin{array}{r}1402131.75 \\
22866653.55\end{array}$ \\
\hline
\end{tabular}


acquisition on the governments and encourages timely competition of projects (due to the less probability of prolonged legal disputes regarding acquisition) by contractors.

- Given the spatial spread of the lakes, PV-EV-based charging stations can be established, reducing the payback period of the plants, enhancing accessibility for electric vehicle users in urban areas and encouraging start-ups, as well as addressing mobility issues using micro-mobility vehicles.

Despite all the positive impacts, there is a need for detailed studies on the impact of floating solar systems on the aquatic ecosystem, stratification of lakes and food chain disruptions. Since most of the floating solar plants are in their nascent stages of operation, a simulation of their biological activities and studying their behaviour would ensure the holistic suitability of FSPV systems. There is a need to scientifically relate the biotics of an ecosystem with the coverage ratio of solar panels to ensure a balanced trade-off between energy production and environmental protection. Another aspect is to quantify the visual pollution of FSPV systems and ensure that they can be incorporated by preserving the aesthetics of the surroundings. Lastly, with increasing solar projects across the nation, hazardous PV waste is estimated to reach $0.04 \mathrm{Mt}$ by 2030 and 4.5 Mt by 2050 (Sinha et al., 2017). It is vital for stringent recycling policies to be enacted to ensure the lifetime sustainability of solar projects.

\section{REFERENCES}

Acharya M and Devraj S (2019) Floating Solar Photovoltaic (FSPV): A Third Pillar to Solar PV Sector? TERI Discussion Paper: Output of the ETC India Project. The Energy and Resources Institute, New Delhi, India. See https://www.teriin.org/project/floating-solarphotovoltaic-fspv-third-pillar-solar-pv-sector (accessed 14/01/2020). BESCOM (Bangalore Electricity Supply Company Limited) (2018) 17th Annual Report 2018-2019. Bangalore Electricity Supply Company Limited, Bengaluru, India. See https://bescom.karnataka.gov.in/storage/pdffiles/Finance $\% 20$ and $\% 20$ GST $\% 20-\% 20$ Annual\%20Report $/ 17$ th\% 20Annual\%20Report\%20FY\%202018-19.pdf (accessed 17/11/2020).

BSI (2000) BS 6920-1:2000: Suitability of non-metallic products for use in contact with water intended for human consumption with regard to their effect on the quality of water. Specification (AMD 14717) (AMD 15475), BSI, London, UK.

Cazzaniga R, Cicu M, Rosa-Clot M et al. (2018) Floating photovoltaic plants: performance analysis and design solutions. Renewable and Sustainable Energy Reviews 81: 1730-1741, https://doi.org/10.1016/j. rser.2017.05.269.

Choi YK (2014) A study on power generation analysis of floating PV system considering environmental impact. International Journal of Software Engineering and its Applications 8(1): 75-84, https://doi.org/ 10.14257/ijseia.2014.8.1.07.

Commerce and Industries Department - Government of Karnataka (2017) Karnataka EV \& Energy Storage Policy - 2017. Government of Karnataka, India. See https://kum.karnataka.gov.in/KUM/PDFS/ KEVESPPolicyInsidepagesfinal.pdf (accessed 23/11/2020).

Dizier A (2018) Techno-Economic Analysis of Floating PV Solar Power Plants Using Active Cooling Technique: A Case Study for Taiwan (Student thesis). KTH School of Industrial Engineering and Management, Stockholm, Sweden, TRITA-ITM-EX 2018. See https:// kth.diva-portal.org/smash/get/diva2:1290021/FULLTEXT01.pdf (accessed 18/10/2020).
Ferrer-Gisbert C, Ferrán-Gozálvez JJ, Redón-Santafé M et al. (2013) A new photovoltaic floating cover system for water reservoirs. Renewable Energy 60: 63-70, https://doi.org/10.1016/j.renene.2013. 04.007.

Gambhir A, Jethmalani R, Sarode J, Das N and Dixit S (2016) India's Journey towards 175 GW Renewables by 2022. Prayas Energy Group, Pune, India. See https://www.prayaspune.org/peg/publications/item/ 329-india-s-journey-towards-175-gw-renewables-by-2022.html (accessed 12/12/2020).

Green M, Emery K, Hishikawa Y et al. (2012) Solar cell efficiency tables (version 40). IEEE Transactions on Fuzzy Systems 20(6): 1114-1129, https://doi.org/10.1002/pip.2267.

Haas J, Khalighi J, de la Fuente A et al. (2020) Floating photovoltaic plants: ecological impacts versus hydropower operation flexibility. Energy Conversion and Management 206: article 112414, https://doi. org/10.1016/j.enconman.2019.112414.

IEA (2021) Jawaharlal Nehru National Solar Mission (Phase I, II and III) - Policies. IEA, Paris, France. See https://www.iea.org/policies/4916jawaharlal-nehru-national-solar-mission-phase-i-ii-and-iii (accessed 11/ 08/2021).

Ishwara RK, Manasa N, Shena B et al. (2017) An empirical study on adaption of solar roofing in Bengaluru City. Journal of Management and Commerce 13(1): 21-24.

Kamuyu WCL, Lim JR, Won CS and Ahn HK (2018) Prediction model of photovoltaic module temperature for power performance of floating PVs. Energies 11(2): 447, https://doi.org/10.3390/en11020447.

Liu L, Wang Q, Lin H et al. (2017) Power generation efficiency and prospects of floating photovoltaic systems. Energy Procedia 105: 1136-1142, https://doi.org/10.1016/j.egypro.2017.03.483.

Mittal D, Saxena BK and Rao KVS (2017) Floating solar photovoltaic systems: an overview and their feasibility at Kota in Rajasthan. In Proceedings of IEEE International Conference on Circuit, Power and Computing Technologies, ICCPCT 2017, pp. 1-7.

NREL (National Renewable Energy Laboratory) (2012) Life Cycle Greenhouse Gas Emissions from Solar Photovoltaics. NREl, Golden, CO, USA. See https://www.nrel.gov/docs/fy13osti/56487.pdf (accessed 03/12/2020).

Oliveira-Pinto S and Stokkermans J (2020) Assessment of the potential of different floating solar technologies - overview and analysis of different case studies. Energy Conversion and Management 211: article 112747, https://doi.org/10.1016/j.enconman.2020.112747.

Oxford Economics (2020) Global Cities: The Future of the World's Leading Urban Economies to 2035, Oxford Economics, Oxford, UK. See https://www.oxfordeconomics.com/recent-releases/7fa5c39e-6603433c-9e59-9dd928fa2415 (accessed 12/01/2020).

Philip CM (2018) Bengaluru airport could switch to total solar power by 2020. The Times of India, 19 June. See https://timesofindia.indiatimes. com/city/bengaluru/airport-could-switch-to-total-solar-power-by-2020/ articleshow/64640081.cms\#: :text=The\%20airport $\% 20$ now $\%$ 20 generates $\% 203.44$,solar $\% 20$ energy $\% 20$ from $\% 20$ off $\% 2$ Dsite (accessed 24/11/2019).

Pimentel Da Silva GD and Branco DAC (2018) Is floating photovoltaic better than conventional photovoltaic? Assessing environmental impacts. Impact Assessment and Project Appraisal 36(5): 390-400, https://doi.org/10.1080/14615517.2018.1477498.

Psomopoulus CS, loannidis GC and Kaminaris SD (2015) A comparative evaluation of photovoltaic electricity production assessment software (PVGIS, PVWatts and RETScreen). Environmental Processes 2(1): 175-189, https://doi.org/10.1007/s40710-015-0092-4.

Redón Santafé M, Torregrosa Soler JB, Sánchez Romero FJ et al. (2014) Theoretical and experimental analysis of a floating photovoltaic cover for water irrigation reservoirs. Energy 67: 246-255, https://doi.org/10. 1016/j.energy.2014.01.083.

Rosa-Clot M and Tina GM (2018) Submerged and Floating Photovoltaic Systems. Academic Press, MA, USA, pp. 89-136. 
Smart Infrastructure and Construction

Volume 174 Issue 1
Feasibility study of floating solar panels

over lakes in Bengaluru City, India

Yashas, Bagrecha and Dhanush
Rosa-Clot M, Tina GM and Nizetic S (2017) Floating photovoltaic plants and wastewater basins: an Australian project. Energy Procedia 134: 664-674, https://doi.org/10.1016/j.egypro.2017.09.585.

Sahu A, Yadav N and Sudhakar K (2016) Floating photovoltaic power plant: a review. Renewable and Sustainable Energy Reviews 66: 815-824, https://doi.org/10.1016/j.rser.2016.08.051.

Serrano O, Ruhon R and Lavery P (2016) Impact of mooring activities on carbon stocks in seagrass meadows. Scientific Reports 6(1): article 23193, https://doi.org/10.1038/srep23193.

Sharma BD (2011) Performance of Solar Power Plants in India. Central Electricity Regulatory Commission (CERC), New Delhi, India. See https://cercind.gov.in/2011/Whats-New/PERFORMANCE $\% 20 \mathrm{OF} \%$ 20SOLAR\%20POWER\%20PLANTS.pdf (accessed 19/11/2019).

Sharma AK and Kothari DP (2016) Floating solar PV potential in large reservoirs in India. International Journal for Innovative Research in Science \& Technology 2(11): 97-101.

Singh AK, Boruah D, Sehgal L and Ramaswamy AP (2019) Feasibility study of a grid-tied 2MW floating solar PV power station and etransportation facility using 'SketchUp Pro' for the proposed smart city of Pondicherry in India. Journal of Smart Cities 2: 49-59, http:// doi.org/10.18063/JSC.2016.02.004.
Sinha P, Raju S, Drozdiak K and Wade A (2017) Life cycle management and recycling of PV systems. PV-Tech Power 13: 47-50.

Subramanya K (2013) Engineering Hydrology, 4th edn. Tata McGrawHill Education, New York, NY, USA, pp. 75-79.

Thomson GW (1946) The Antoine equation for vapor-pressure data. Chemical Reviews 38: 1-39, https://doi.org/10.1021/cr60119a001.

Trapani K and Redón Santafé M (2015) A review of floating photovoltaic installations: 2007-2013. Progress in Photovoltaics: Research and Applications 23(4): 524-532, https://doi.org/10.1002/pip.2466.

Tyagi AP (2009) Solar Radiant Energy over India. India Meteorological Department (IMD), Pune, India. See https:/cercind.gov.in/2011/ Whats-New/PERFORMANCE\%20OF\%20SOLAR\%20POWER\% 20PLANTS.pdf (accessed 23/11/2019).

Wesoff E and Lacey S (2017) Solar costs are hitting jaw-dropping lows in every region of the world. Green Tech Media, 27 June. See https:// www.greentechmedia.com/articles/read/solar-costs-are-hitting-jawdropping-lows-in-every-region-of-the-world (accessed 23/12/2019).

World Bank Group; Energy Sector Management Assistance Program; Solar Energy Research Institute of Singapore (2019) Where Sun Meets Water: Floating Solar Market Report. World Bank, Washington, DC, USA. See https://openknowledge.worldbank.org/handle/10986/31880.

\section{How can you contribute?}

To discuss this paper, please email up to 500 words to the editor at journals@ice.org.uk. Your contribution will be forwarded to the author(s) for a reply and, if considered appropriate by the editorial board, it will be published as discussion in a future issue of the journal.

Proceedings journals rely entirely on contributions from the civil engineering profession (and allied disciplines). Information about how to submit your paper online is available at www.icevirtuallibrary.com/page/authors, where you will also find detailed author guidelines. 